\title{
Inovasi Model Pembelajaran PBI (Problem Based Instruction) Berbasis Whatsapp Sebagai Langkah Solutif Pembelajaran di Masa Pandemi Covid-19
}

\author{
Ucu Rosmiati $^{1^{*}}$, Puji Lestari ${ }^{2}$ \\ ${ }^{1}$ Magister Pendidikan Matematika, Universitas Siliwangi,Tasikmalaya, Indonesia; \\ 1*ucurosmiati151@gmail.com; ${ }^{2}$ pujilestari@unsil.ac.id
}

Info Artikel: Dikirim: 9 Juli 2020 ; Direvisi: 16 Februari 2021; Diterima: 2 Maret 2021 Cara sitasi: Rosmiati, U., \& Lestari, P. (2021). Inovasi Model Pembelajaran PBI (Problem Based Instruction) Berbasis Whatsapp Sebagai Langkah Solutif Pembelajaran di Masa Pandemi Covid19. JNPM (Jurnal Nasional Pendidikan Matematika) 5(1), 188-197.

\begin{abstract}
Abstrak. Adanya pandemi Covid-19 ini mengharuskan kegiatan pembelajaran dilakukan di rumah secara daring. Hal ini mengharuskan pendidik untuk melakukan inovasi yang dapat membuat peserta didik termotivasi dalam melakukan kegiatan pembelajaran. Mengkombinasikan model pembelajaran PBI (Problem Based Instruction) berbasis whatsapp menjadi salah satu pilihan bentuk inovasi pembelajaran selama daring. Dengan demikian tujuan penelitian ini adalah mengetahui hasil implementasi model pembelajaran PBIberbasis whatsapp dan mendeskripsikan sikap peserta didik terhadap model tersebut. Metode penelitian yang digunakan adalah kualitatif deskriptif. Respon peserta didik terhadap inovasi pembelajaran ini cukup baik. Hal ini karena implementasi model pembelajaran PBI yang dikombinasikan dengan media whatsapp merupakan sesuatu yang baru dan cukup menarik bagi peserta didik.Hasil angket pada penelitian ini menunjukkan interpretasi baik,sehingga model pembelajaran PBI (Problem Based Instruction) berbasis whatsap ini layak digunakan sebagai solusi pembelajaran di masa pandemi Covid-19.
\end{abstract}

Kata Kunci: Pandemi Covid-19, Model Pembelajaran PBI, Whatsapp.

\begin{abstract}
The existence of the Covid-19 pandemic requires learning activities to be carried out at home online. It requires educators to make innovations that can make students motivated in carrying out learning activities. Combining the WhatsApp-based PBI (Problem Based Instruction) learning model is an option for innovative online learning forms. Thus, this study aims to determine the results of implementing the WhatsApp-based PBI learning model and describe the attitudes of students towards the model. The research method used is descriptive qualitative. The response of students to this learning innovation is quite good. Implementing the PBI learning model combined with the WhatsApp media is something new and quite interesting for students. This study's questionnaire results showed a reasonable interpretation so that the WhatsApp-based PBI (Problem Based Instruction) learning model was suitable for use as a learning solution during the Covid-19 pandemic. Keywords: Covid-19 Pandemic, PBI Learning Model, Whatsapp.
\end{abstract}

Keywords: The Covid-19 Pandemic, PBI Learning Model, Whatsapp.

\section{Pendahuluan}

Kasus pandemi Covid-19 yang kian masif ini mengharuskaan seluruh kegiatan dijalankan dari rumah termasuk kegiatan belajar mengajar. Hal ini 
sejalan dengan (Menteri Pendidikan dan Kebudayaan Republik Indonesia, 2020) mengenai surat edaran Nomor 4 Tahun 2020 Tentang PelaksanaanKebijakan Pendidikan Dalam Masa DaruratPenyebaran Covid19. Dalam surat edaran tersebut dijelaskan bahwa proses belajar dilaksanakan dirumah melalui pembelajaran daring. Hal inidilakukan untuk memberikan pengalamanbelajar yang bermakna bagi peserta didik. Belajar dari rumah (study from home) merupakan salah satu kebijakan dari pemerintah yang diperuntukan bagi peserta didik yang berlaku untuk sementara waktu. Hal ini dilakukan guna meminimalisir kontak fisik secara massal sehingga dapat memutus mata rantai penyebaran virus corona tersebut. Sejalan dengan hal tersebut maka menurut(Arizona, Abidin \& Rumansyah, 2020) bahwa digitalisasi sistem pada revolusi industri 4.0 ini menuntut para pendidik dan peserta didik untuk mampu dengan cepat beradaptasi dengan perubahan yang ada. Salah satunya adalah sistem pembelajaran yang pada awalnya dilakukan secara tatap muka maka bukan tidak mungkin akan dapat digantikan dengan sistem pembelajaran yang terintegrasikan melalui jaringan internet (online).

Adanya pandemi Covid 19 ini secara tidak langsung sudah mendorongbanyak profesional di dunia pendidikan untukterjun lebih dalam, khususnya dalam penguasaan teknologi digital, yang selama inimungkin hanya sebatas internet dan email,dan itupun mungkin hanya digunakan untukkeperluan tertentu saja (Naserly, 2020). Ada banyak aplikasi yang dapat digunakan untuk memfasilitasi pembelajaran daring ini yaitu seperti videoconverence, live chat, zoommaupun melalui whatsapp grup.Pembelajaran daring ini merupakaninovasi pendidikan untuk menjawab tantanganakan ketersediaan sumber belajar yang variatif (Dewi, 2020). Keberhasilan model ataupun mediapembelajaran tergantung dari karakteristik pesertadidiknya. Hal ini sejalan dengan yang diungkapkan oleh (Nakayama, Yamamoto \& Santiago, 2007) yaitu elearning mengindikasikan bahwa tidak semua peserta didik akan sukses dalam pembelajaran online. Hal ini dikarenakan faktor lingkungan belajar dan karakteristik peserta didik itu sendiri. Media daring dirasa efektif dilakukan sebagai langkah solutif untuk mencegah penyebaran Covid-19 di lingkungan pendidikan salah satunya adalah menggunakan media whatsapp. Whatsapp merupakan aplikasi berbasis mobile phone dan web yang terintegrasi dengan berbagai aplikasi yang digunakan untuk berkomunikasi dengan pengguna lainnya (Prajana, 2017). Sehingga menurut (Pustikayasa, 2019) media pembelajaran whatsapp memiliki dampak positif pada kesuksesan pembelajaran dan penggunaannya disambut secara substansial. Penggunaanmedia sosial whatsapp sudah menjadi salah satumedia sosial yang mencakup keseluruhankepentingan masyarakat. Hal 
ini menjadikan whatsapp sebagai aplikasi yang setiap harinya pesera didik gunakan untuk melakukan komunikasi. Sehingga menjadikan whatsapp menjadi salah satu media pembelajaran yang saat ini banyak digandrungi pendidik dalam proses pembelajaran daring. Berdasarkan hasil penelitian (Yensy, 2020) bahwa hasil belajar matematika menggunakan media whatsapp grup sangat efektif dilakukan di masa pandemi Covid-19 ini. Namun, terdapat beberapa kendala yang dihadapi oleh peserta didik dengan adanya pembelajaran daring ini salah satunya adalah gadget, kuota internet, dan sinyal. Hal ini sejalan dengan hasil penelitian (Rachmat \& Krisnadi, 2020) yaitu bahwa kendala yang dihadapi peserta didik dalam pembelajaran daring adalah kuota data yang terbatas dan jaringan internet yang lambat.

Pembelajaran secara online tanpa adanya sinergitas strategi dan metode pembelajaran tentunya akan kurang bermakna. Maka dari itu pada penelitian ini peneliti mengombinasikan media whatsapp dengan model pembelajaran PBI (Problem Based Instruction) yang selanjutnya disebut model pembelajaran PBI.Model pembelajaran PBI merupakan model pembelajaran yang berlandaskan pada paham konstruktivistik yang mengakomodasi keterlibatan peserta didik dalam belajar dan pemecahan masalah otentik (Muah, 2016). Menurut Komalasari model PBI memiliki sintaks yang terdiri dari 5 langkah, yaitu mengorientasi peserta didik kepada masalah, mengorganisasi peserta didik untuk belajar, membantu peserta didik melakukan penyelidikan mandiri dan kelompok, mengembangkan dan menyajikan hasil karya dan memamerkannya, dan menganalisis dan mengevaluasi proses pemecahan masalah (Mustamiroh, Hidayati \& Hadi, 2019). Model pembelajaran PBI menuntut peserta didik untuk meghasilkan suatu produk/karya yang berhubungan dengan materi yang sedang dipelajari. Produk/karya yang dihasilkan nantinya akan dipamerkan melalui story whatsapp masing-masing peserta didik untuk kemudian akan diberikan penilaian oleh pendidik. Hal ini tentunya dapat menumbuhkan kreativitas peserta didik. Hal ini sejalan dengan hasil penelitian (Dewi, Bektiarso \& Subiki, 2017) yaitu bahwa model pembelajaran PBI berpengaruh signifikan terhadap hasil belajar peserta didik.

Kombinasi antara model pembelajaran PBI berbasis whatsapp merupakan inovasi baru yang dilakukan peneliti terutama pada masa pandemi Covid-19 ini guna membuat pembelajaran daring menjadi lebih menarik. Tantangan perihal alih sistem pembelajarandari tatap muka menjadi daring inilah yangmembuat peneliti ingin mengangkat temapenelitian ini dengan tujuan untuk mengimplementasikan model pembelajaran PBI berbasis whatsapp pada pembelajaran di masa pandemi Covid-19. 


\section{Metode}

Pada penelitian ini penulis menggunakan metode kualitatif deskriptif dalam menjabarkan analisis yang telah dilakukan. Instrumen penelitian yang digunakan pada penelitian ini adalah angket respon siswa yang telah divalidasi dan dinyatakan layak untuk diberikan kepada siswa dalam penelitian ini.Responden pada penelitian ini adalah kelas XI jurusan OTKP di salah satu Sekolah Menengah Kejuruan di Kabupaten Tasikmalaya.Pemilihan responden pada penelitian ini berdasarkan kesiapan peserta didik dalam mengikuti pembelajaran daring yang dilakukan oleh peneliti. Pemilihan subjek penelitian dilakukan secara purposive. Purposive merupakan pengambilan subjek penelitian yang didasarkan pada tujuan atau pertimbangan tertentu (Yusuf, 2017). Pertimbangan yang dimaksud yaitu peserta didik yang bersedia untuk berkontribusi dalam penelitian ini yang didukung dengan kuota internet yang memadai dan sinyal internet yang kuat. Dari 11 orang peserta didik, yang sesuai dengan pertimbangan peneliti untuk dijadikan subjek penelitian hanya 8 peserta didik.

\section{Hasil dan Pembahasan}

Hal pertama yang dilakukan dalam mengimplementasikan model pembelajaran PBI berbasis whatsapp adalah membuat grup whatsapp kelas. Pembelajaran dilaksanakan satu kali dengan materi yang disampaikan adalah sudut bangun datar, keliling bangun datar, dan luas daerah bangun datar. Pada waktu pembelajaran dimulai peserta didik melakukan absensi di grup whatsapp dengan melakukan foto selfie dan menuliskan kata "Hadir" maka dengan melakukan hal tersebut peserta didik dianggap hadir dalam kegiatan pembelajaran. Pada Gambar 1 berikut ini merupakan format hasil absensi siswa melalui grup whatsapp.

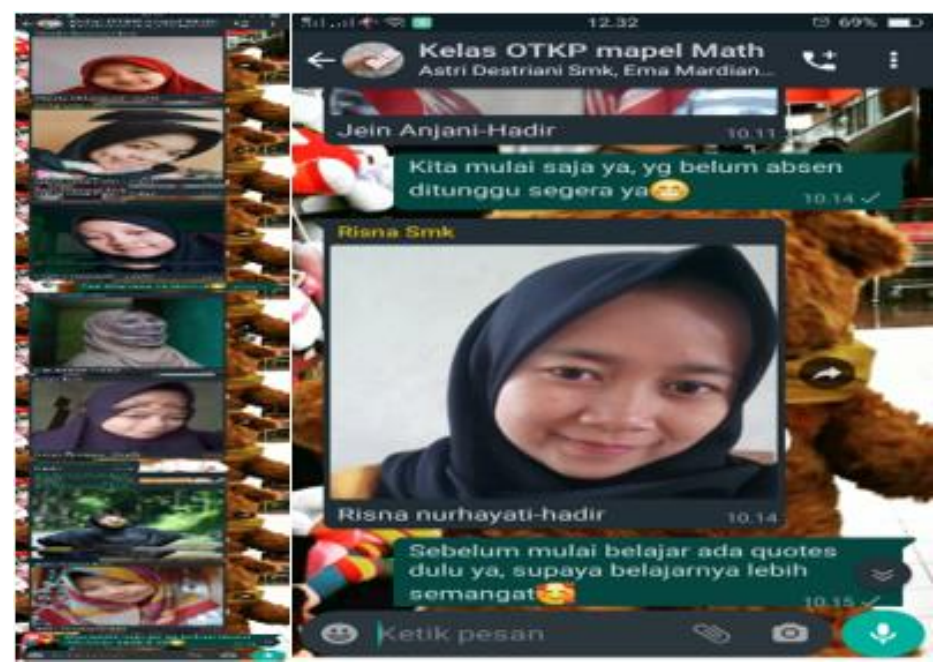

Gambar 1. Absensi Peserta Didik 
Setelah itu, peserta didik memahami materi pembelajaran yang telah peneliti berikan. Selanjutnya apabila ada sesuatu yang tidak dipahami oleh peserta didik dapat didiskusikan bersama di grup whatsapp. Setelah itu, peserta didik diberikan latihan soal berupa soal uraian sebanyak empat soal sebagai bahan evaluasi kemudian hasil jawaban dari latihan soal tersebut difotokan dan selanjutnya dikirimkan secara personal chat ke whatsapp pribadi peneliti. Pada gambar 2 merupakan salah satu contoh hasil pengerjaan quis peserta didik.

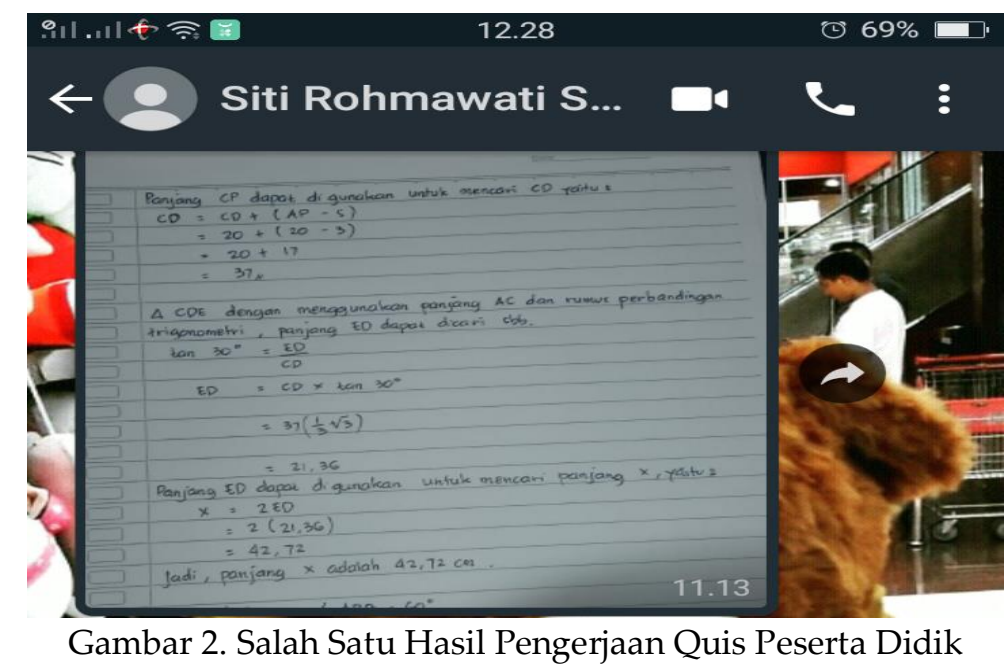

Selanjutnya, peserta didik diarahkan untuk membuat suatu karya/produk yang berhubungan dengan materi pelajaran matematika yang sebelumnya telah dipelajari. Setelah itu, hasil karya tersebut dipamerkan di postingan story whatsapp masing-masing peserta didik. Pada Gambar 3, 4, dan 5 berikut inimerupakan hasil karya yang telah dibuat oleh masing-masing peserta didik. Namun, dari 8 peserta didik yang mengikuti pembelajarandari awal hanya 7 peserta didik yang membuat suatu karya untukdipamerkan.

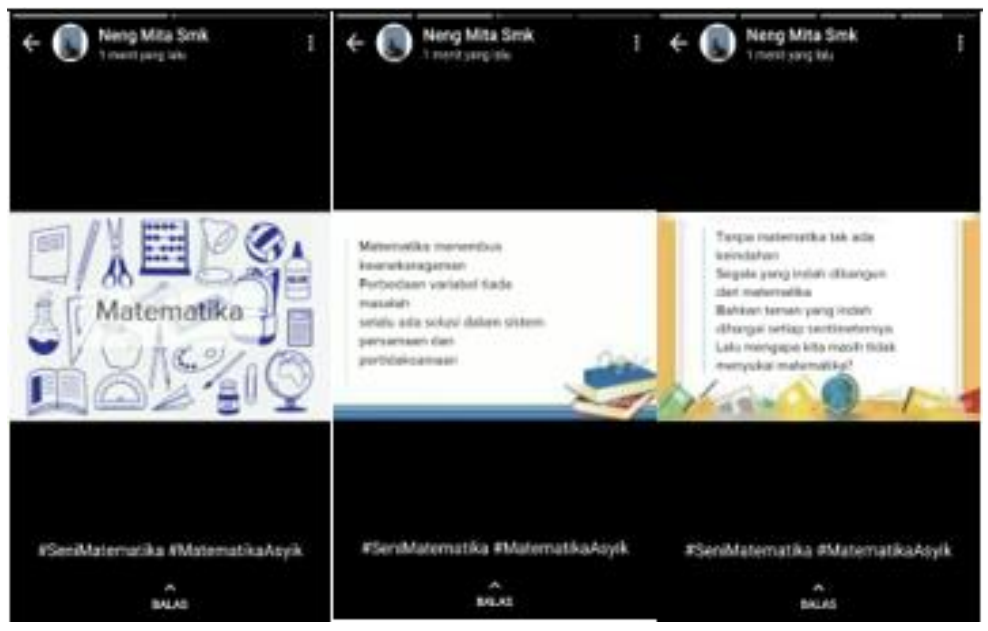

Gambar 3. Hasil Karya Peserta Didik ke-1 
Berdasarkan Gambar 3, peserta didik ke-1 membuat suatu karya berupa vidio puisi yang berhubungan dengan materi yang sebelumnya telah dipelajari. Jadi, karya puisi yang dibuat oleh peserta didik ke-1 memasukan unsur-unsur bangun datar, keliling bangun datar, dan luas daerah bangun datar dalam naskah puisinya. Implementasi inovasi pembelajara ini selain memberikan pembelajaran matematika menjadi lebih menarik tetapi juga mengasah kemampuan peserta didik dalam bidang teknologi dan kreatifitas. Hal ini tentunya merupakan suatu inovasi baru dalam pembelajaran matematika untuk membuat pembelajaran matematika menjadi lebih menarik, terutama pada situasi pandemi covid-19 ini.

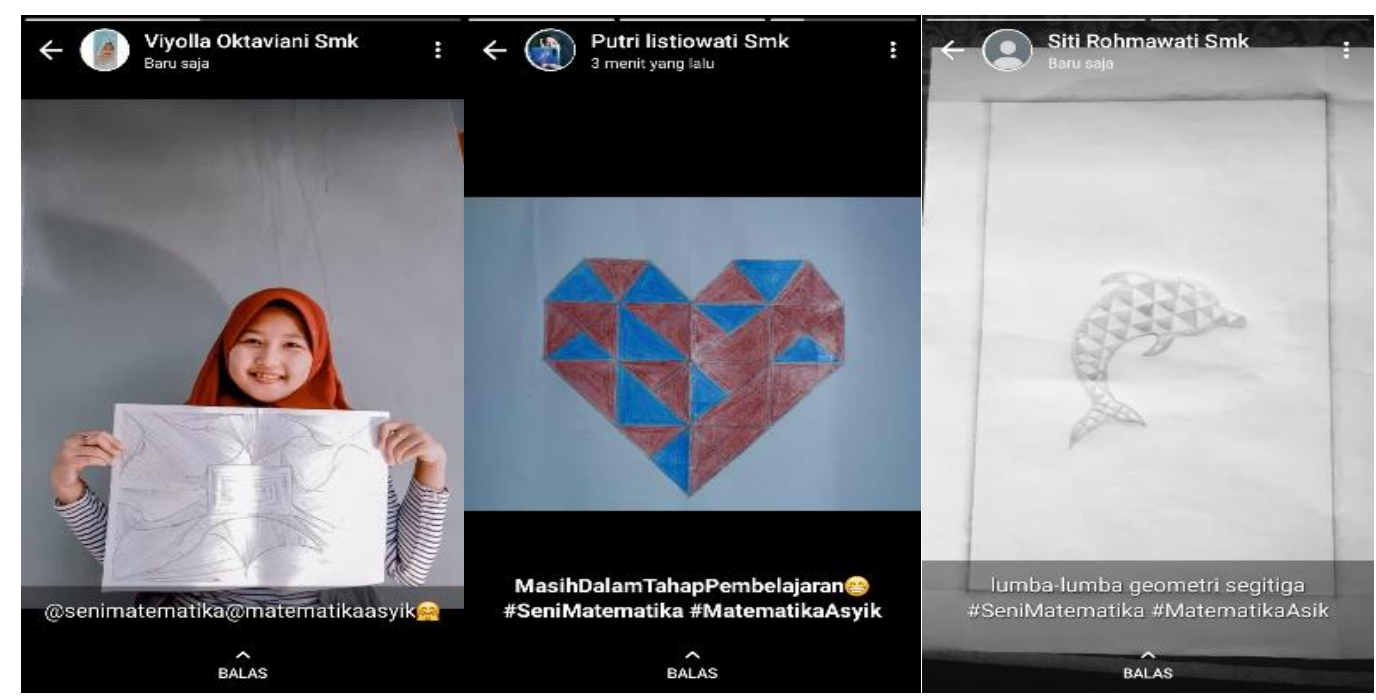

Gambar 4. Hasil Karya Peserta Didik ke2, 3, dan 4

Berdasarkan Gambar 5, peserta didik ke 2, 3, dan 4 membuat suatu karya berupa gambar geometri yang berhubungan dengan materi yang sebelumnya telah dipelajari. Jadi, karya berupa gambar geometri yang dibuat oleh peserta didik tersebut memasukan unsur-unsur bangun datar, keliling bangun datar,dan luas daerah bangun datar dalam lukisannya tersebut. Hal ini tentunya merupakan suatu inovasi baru dalam pembelajaran matematika untuk membuat pembelajaran matematika menjadi lebih menarik dengan mengeksplor bakat dan kreatifitas yang dimiliki oleh peserta didik, terutama pada situasi pandemi covid-19 ini. 


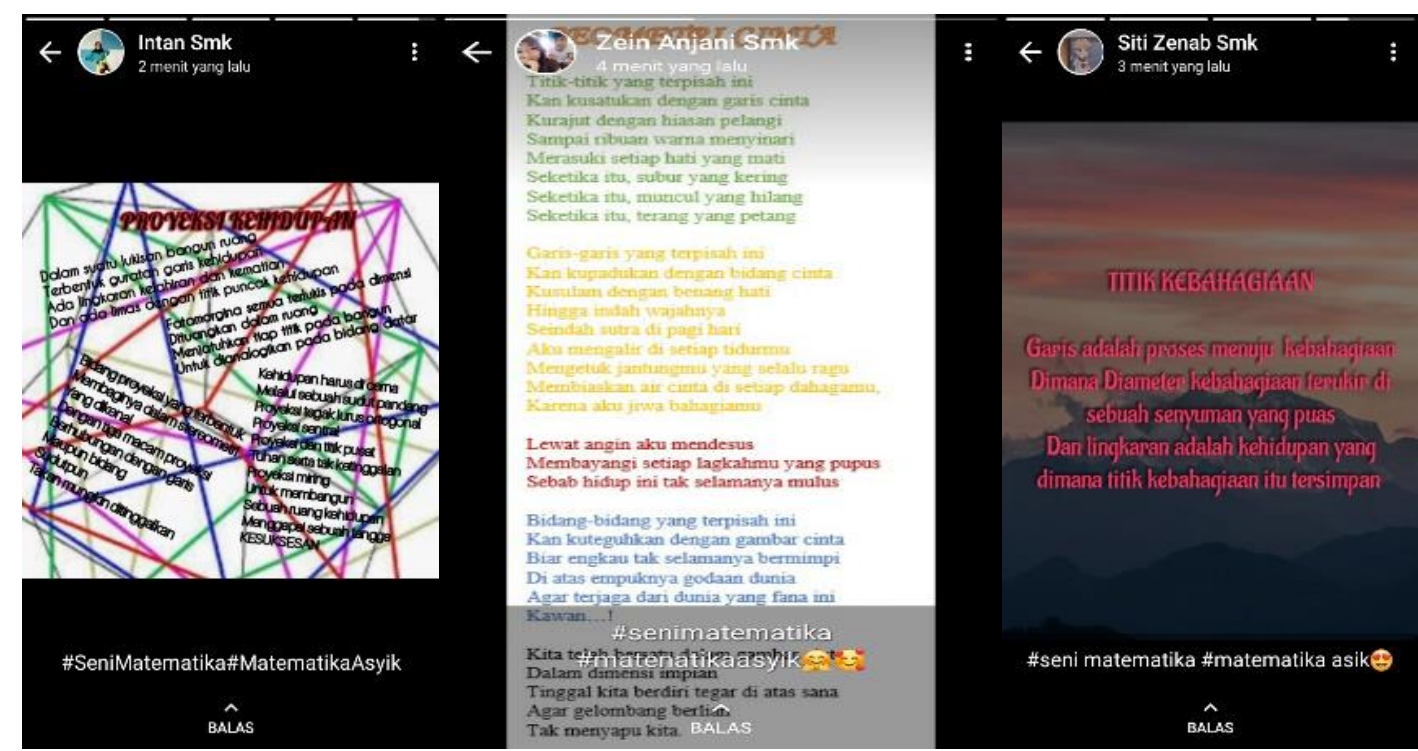

Gambar 5. Hasil Karya Peserta Didik ke 5, 6, dan 7

Sama halnya dengan Gambar 3, berdasarkan Gambar 5 peserta didik ke-1 membuat suatu karya berupa vidio puisi yang berhubungan dengan materi yang sebelumnya telah dipelajari. Jadi, karya puisi yang dibuat oleh peserta didik ke 5, 6, dan 7 memasukan unsur-unsur bangun datar, keliling bangun datar, dan luas daerah bangun datar dalam naskah puisinya. Hal ini tentunya merupakan suatu inovasi baru dalam pembelajaran matematika untuk membuat pembelajaran matematika menjadi lebih menarik, terutama pada situasi pandemi covid-19 ini.

Setelah pembelajaran selesai dilakukan, peneliti melakukan evaluasi dengan memberikan angket kepada peserta didik. Adapun hasil skala perhitungan yang telah dilakukan adalah sebagai berikut.

Skor Maksimum $\left(\mathrm{S}_{\text {maks }}\right)=$ banyak butir angket $\times$ banyak responden $\times 5$

$$
\begin{aligned}
& =10 \times 8 \times 5 \\
& =400
\end{aligned}
$$

Skor Minimum $\left(\mathrm{S}_{\min }\right)=$ banyak butir angket $\times$ banyak responden $\times 1$

$$
\begin{aligned}
& =10 \times 8 \times 1 \\
& =80
\end{aligned}
$$

Rentang $=\mathrm{S}_{\text {maks }}-\mathrm{S}_{\min }$

$$
\begin{aligned}
& =400-80 \\
& =320
\end{aligned}
$$

$\mathrm{p}=\frac{\text { Rentang }}{\text { Kategori }}=\frac{320}{5}=64$

Dengan interpretasi skor total pada Tabel 1. 
Tabel 1. Interpretasi

\begin{tabular}{cc}
\hline Skor Total & Interpretasi \\
\hline $\mathbf{8 0} \leq$ ST $<\mathbf{1 4 4}$ & Sangat Jelek \\
$\mathbf{1 4 4} \leq$ ST $<\mathbf{2 0 8}$ & Jelek \\
$\mathbf{2 0 8} \leq$ ST $<\mathbf{2 7 2}$ & Cukup \\
$\mathbf{2 7 2} \leq$ ST $<\mathbf{3 3 6}$ & Baik \\
$\mathbf{3 3 6} \leq$ ST $<\mathbf{4 0 0}$ & Sangat Baik \\
\hline
\end{tabular}

- Responden yang menjawab Sangat Setuju $18 \times 5=90$

- Responden yang menjawab Setuju $37 \times 4=148$

- Responden yang menjawab Kurang Setuju $20 \times 3=60$

- Responden yang menjawab Tidak Setuju $4 \times 2=8$

- Responden yang menjawab Sangat Tidak Setuju $1 \times 1=1$

Berdasarkan skala perhitungan di atas diperoleh skor total $=307$ yang berada pada rentang $272 \leq 307<336$ dengan interpretasi "Baik". Jadi, respon peserta didik mengenai inovasi pembelajaran yang dilakukan oleh peneliti dengan menggunakan model pembelajaran PBI berbasis whatsapp cukup baik karena pembelajaran ini merupakan sesuatu yang baru bagi peserta didik menginggat hal ini belum pernah dilakukan sebelumnya. Hal ini sejalan dengan yang diungkapkan (Rachmat \& Krisnadi, 2020) bahwa model pembelajaran PBI adalah model pembelajaran yang mampu meningkatkan aktivitas dan hasil belajar peserta didik. Selain itu, model pembelajaran PBI yang dikombinasikan dengan media whatsapp membuat kegiatan pembelajaran daring menjadi lebih menarik dan mampu meningkatkan motivasi dan minat belajar peserta didik. Sesuai dengan yang diungkapkan oleh (Singgih \& Suparwoto, 2018) bahwa media sumber belajar mandiri berbasis aplikasi layanan whatsapp dapat meningkatkan motivasi dan hasil belajar peserta didik. Sejalan dengan hal tersebut (Barhoumi, 2020) mengatakan bahwa kegiatan pembelajaran menggunakan aplikasi grup whatsapp membawa manfaat bagi prestasi dan sikap peserta didik terhadap pembelajaran dan pendidikan secara mobile.

\section{Simpulan}

Peserta didik memiliki respons dan interpretasi yang baik dengan adanya inovasi pembelajaran daring menggunakan model pembelajaran PBI berbasis whatsapp ini. Selain itu, dengan digunakannya model pembelajaran PBI yang merupakan model pembelajaran yang baru bagi peserta didik membuat pembelajaran menjadi lebih menarik dan peserta didik menjadi sangat antusias. Namun, tidak dapat dipungkiri bahwa terdapat beberapa kendala 
yang terjadi dalam pembelajaran daring ini, diantaranya adalah gadget, sinyal dan kuota internet.

Pada masa pamdemi covid-19 ini menggunakan model pembelajaran PBI berbasis whatsapp dalam pembelajaran daring merupakan salah satu alternatif yang dapat dilakukan. Adapaun saran pada penelitian ini adalah buatlah media pembelajaran daring yang setiap waktu kita buka karena membutuhkannya dan lakukan pembaharuan terhadap media pembelajaran tersebut sehingga membuat pembelajaran menjadi lebih efektif dan menyenangkan dan peserta didik menjadi termotivasi dan meningkatkan semangat belajarnya walaupun pembelajaran dilakukan secara online.

\section{Daftar Pustaka}

Arizona, K., Abidin, Z., \& Rumansyah, R. (2020). Pembelajaran Online Berbasis Proyek Salah Satu Solusi Kegiatan Belajar Mengajar di Tengah Pandemi Covid-19. Jurnal Ilmiah Profesi Pendidikan, 5(1), 64-70. https://doi.org/10.29303/jipp.v5i1.111

Barhoumi, C. (2020). The Effectiveness of WhatsApp Mobile Learning Activities Guided by Activty Theory on Students' Knowldege Management. Contemporary Educational Technology, 6(3), 221-238. https://doi.org/10.30935/cedtech/6151

Dewi, D. A. D. R., Bektiarso, S., \& Subiki. (2017). Pengaruh Model Pembelajaran Problem Based Instruction Disertai Metode Pictorial Riddle Terhadap Hasil Belajar Dan Kemampuan Berpikir Kritis Siswa Pada Mata Pelajaran Fisika Di Sma. Jurnal Pembelajaran Fisika, 6(1), 48-55.

Dewi, W. A. F. (2020). Dampak COVID-19 terhadap Implementasi Pembelajaran Daring di Sekolah Dasar. Edukatif: Jurnal Ilmu Pendidikan, 2(1), 55-61. https://doi.org/10.31004/edukatif.v2i1.89

Menteri Pendidikan dan Kebudayaan Republik Indonesia. (2020). Surat Edaran Nomor 4 Tahun 2o2o Tentang Pelaksanaan Kebijakan Pendidikan Dalam Masa Darurat Penyebaran Co Ro Naviru S D/Sease (Covid- 19). Surat Edaran Nomor 4 Tahun 2020.

Muah, T. (2016). Instruction (Pbi) Untuk Meningkatkan Keaktifan Dan Hasil Belajar Matematika Siswa Kelas 9b Semester Gasal Tahun Pelajaran 2014 / 2015 Smp Negeri 2 Tuntang - Semarang. Scholaria, 6(1), 41-53.

Mustamiroh, R., Hidayati, Y., Hadi, W. P., \& Muharrami, L. K. (2019). Penerapan Model Pembelajaran Problem Based Instruction (Pbi) Berbasis Open Ended Terhadap Keterampilan Berpikir Kritis Siwa. Journal of Natural Science and Education Research, 1(2), 124-137.

Nakayama, M., Yamamoto, H., \& Santiago, R. (2007). Relationship between learner characteristics and learning performance in hybrid courses among Japanese students. Proceedings of the International Conference on E-Learning, ICEL, 2007-Janua(3), 341-349.

Naserly, M. K. (2020). Implementasi Zoom, Google Classroom, Dan Whatsapp Group Dalam Mendukung Pembelajaran Daring (Online) Pada Mata Kuliah Bahasa Inggris Lanjut. Journal of Chemical Information and Modeling, 4(2), 155-165.

Prajana, A. (2017). Pemanfaatan Aplikasi Whatsapp Untuk Media Pembelajaran Dalam Lingkungan Uin Ar-Raniry Banda Aceh. Cyberspace: Jurnal Pendidikan Teknologi Informasi, 1(2), 122. https://doi.org/10.22373/cs.v1i2.1980

Pustikayasa, I. M. (2019). Grup WhatsApp Sebagai Media Pembelajaran. Widya Genitri : Jurnal Ilmiah Pendidikan, Agama Dan Kebudayaan Hindu, 10(2), 53-62. 
https://doi.org/10.36417/widyagenitri.v10i2.281

Rachmat, A., \& Krisnadi, I. (2020). Analisis Efektifitas Pembelajaran Daring (Online) Untuk Siswa SMK Negeri 8 Kota Tangerang Pada Saat Pandemi Covid 19. Jurnal Pendidikan, 1(1), $1-7$.

Singgih, H. A., \& Suparwoto. (2018). Pengembangan Media Belajar Mandiri Berbasis Aplikasi WhatsApp Untuk Meningkatkan Motivasi Dan Hasil Belajar Fisika Kelas Xi SMA N 1 Purwokerto. Jurnal Pendidikan Fisika, 7(1), 32-38.

Yensy, N. A. (2020). Efektifitas pembelajaran statistika matematika melalui media whatsapp group ditinjau dari hasil belajar mahasiswa (masa pandemik Covid 19). Jurnal Pendidikan Matematika Raflesia, 05(02), 65-74.

Yusuf, M. (2017). Metode Penelitian: Kuantitatif, Kualitatf \& Penelitian Gabungan. Kencana Perenada. 